\title{
A study of virulence and antimicrobial resistance pattern in diarrhoeagenic Escherichia coli isolated from diarrhoeal stool specimens from children and adults in a tertiary hospital, Puducherry, India
}

\author{
Mailan Natarajan ${ }^{1}$, Deepika Kumar ${ }^{1}$, Jharna Mandal ${ }^{1 *}$, Niranjan Biswal ${ }^{2}$ and Selvaraj Stephen ${ }^{3}$
}

\begin{abstract}
Background: Emergence of atypical enteropathogenic Escherichia coli (EPEC) and hybrid E. coli (harboring genes of more than one DEC pathotypes) strains have complicated the issue of growing antibiotic resistance in diarrhoeagenic Escherichia coli (DEC). This ongoing evolution occurs in nature predominantly via horizontal gene transfers involving the mobile genetic elements like integrons notably class 1 integron. This study was undertaken to determine the virulence pattern and antibiotic resistance among the circulating DEC strains in a tertiary care center in south of India.

Methods: Diarrhoeal stool specimens were obtained from 120 children ( $<5$ years) and 100 adults ( $>18$ years), subjected to culture and isolation of diarrhoeal pathogens. Conventional PCR was performed to detect 10 virulence and 27 antimicrobial resistance (AMR) genes among the E. coli isolated.

Results: DEC infection was observed in 45 (37.5\%) children and 18 (18\%) adults, among which [18 (40\%), 10 (10\%)] atypical EPEC was most commonly detected followed by [6 (13.3\%), 4 (4\%)] ETEC, [5 (11.1\%) 2 (2\%)] EAEC, [(3 (6.6\%), 0 (0\%)] EIEC, [3 (6.6\%), 0 (0\%] typical EPEC, and [4 (8.8\%), 1 (1\%)] STEC, and no NTEC and CDEC was detected. DEC co-infection in $3(6.6 \%)$ children, and $1(1 \%)$ adult and sole hybrid DEC infection in $3(6.6 \%)$ children was detected. The distribution of sulphonamide resistance genes (sull, sulll, and sulllI were 83.3 and $21 \%, 60.41$ and $42.1 \%$, and 12.5 and 26.3\%, respectively) and class 1 integron (int 1) genes (41.6 and 26.31\%) was higher in DEC strains isolated from children and adults, respectively. Other AMR genes detected were $\operatorname{qn} \mathrm{r} S$, $\operatorname{anr} B, \operatorname{aac}\left(6^{\prime}\right) \mid b-c r$, $\operatorname{dhfr} 1, \operatorname{aad} B, \operatorname{aac}(3)-I V$, tetA, tetB, tetD, catl, blaCTX, blaSHV, and blaTEM. None harbored gnrA, gnrC, gepA, tetE, tetC, tetY, ermA, mcr1, int2, and int3 genes.
\end{abstract}

Conclusions: Atypical EPEC was a primary etiological agent of diarrhea in children and adults among the DEC pathotypes. Detection of high numbers of AMR genes and class 1 integron genes indicate the importance of mobile genetic elements in spreading of multidrug resistance genes among these strains.

Keywords: Diarrhoeagenic Escherichia coli (DEC), Diarrhea, Children, Adults, Antimicrobial resistance (AMR) genes

\footnotetext{
*Correspondence: drjharna@gmail.com

'Department of Microbiology, Jawaharlal Institute of Postgraduate Medical

Education and Research (JIPMER), Puducherry 605006, India

Full list of author information is available at the end of the article
}

(c) The Author(s). 2018 Open Access This article is distributed under the terms of the Creative Commons Attribution 4.0 International License (http://creativecommons.org/licenses/by/4.0/), which permits unrestricted use, distribution, and reproduction in any medium, provided you give appropriate credit to the original author(s) and the source, provide a link to the Creative Commons license, and indicate if changes were made. The Creative Commons Public Domain Dedication waiver (http://creativecommons.org/publicdomain/zero/1.0/) applies to the data made available in this article, unless otherwise stated. 


\section{Background}

Diarrhoeal disease is a major cause of morbidity in all age groups, and it is the second most important cause of mortality in children less than 5 years of age. Though being treatable, burden accounts for 1700 million cases of diarrhea and 5,000,000 deaths among children annually [1]. According to recent data, 10-13 children under 5 years of age die every $1 \mathrm{~h}$ due to diarrhea in India [2]. A high incidence of diarrhoeal diseases has also been documented in adults [3]. One of the most common bacterial agents of infective diarrhea is Escherichia coli. Few studies conducted in India have documented a high prevalence of diarrhoeagenic Escherichia coli (DEC) in children and adults [4]. Most strains of E. coli are intestinal commensal flora of human, birds, and animals. While few strains can cause a variety of intestinal diseases like food poisoning, abdominal cramping, pain or tenderness, nausea, vomiting, and diarrhea both in human and animals, the severity of infection in the host ranges from mild to life-threatening.

Based on the virulence factors, pathogenicity and clinical manifestation E. coli strains are categorized into five pathotypes, namely enterotoxigenic E. coli (ETEC), enteropathogenic E. coli (EPEC), Shiga toxin-producing E. coli (STEC), Enteroinvasive E. coli (EIEC), and Enteroaggregative E. coli (EAEC), which are collectively termed as DEC and have been associated with worldwide outbreaks since 1952 in children, adolescents, and adults [5, 6]. Recent studies from Africa, Spain, India, China, Mexico, and Japan have documented evolving variants like atypical and hybrid strains of DEC where they also noticed an increase in the severity of infection when compared to infection caused by typical DEC strains [4].

Apart from these DEC pathotypes, few extraintestinal $E$. coli were also responsible for intestinal infection in humans and animals like cell-detaching E. coli (CDEC) and necrotoxic E. coli (NTEC) which are known to produce cytotoxic necrotizing factors (CFN 1\&2). Small outbreaks have been reported by these pathotypes in a few places $[7,8]$.

In view of increased consumption of prophylactic antibiotic agents by international travelers, selective pressure by these allows the resistant organism to survive and propagation of antimicrobial resistance (AMR) genes among these strains which is primarily due to horizontal gene transfer (HGT) [9, 10]. Worldwide studies have documented the high prevalence and varying pattern of AMR in DEC [11-16]. On the other hand, there is inadequate information concerning AMR pattern and the molecular resistance mechanisms in DEC from our region. Hence, this study was undertaken to look for DEC and its variants as well as to study the AMR mechanisms operating in them.

\section{Methods}

\section{Study design and site}

This cross-sectional study was carried out from July 2015 to June 2016 on diarrhoeal stool specimens from children (less than 5 years of age) and adults (more than 18 years of age) at JIPMER (a tertiary care public hospital cum research institute) situated in Pondicherry, India.

\section{Specimens and bacterial isolates}

A total of 220 consecutive diarrhoeal stool specimens were collected from 120 children and 100 adults. The samples were inoculated on to MacConkey agar (MAC) from which three to five colonies were picked and inoculated into $2 \mathrm{ml}$ Luria-Bertani (LB) broth; the isolates were stored in LB with $50 \%$ of glycerol and stored in $-80{ }^{\circ} \mathrm{C}$ till further use. DNA was extracted from the $E$. coli isolates using QIAamp DNA Mini Kit (Qiagen, Hilden, Germany). Stool specimens was subjected to culture for the detection of other bacterial agents causing diarrhea using standard protocol on to MAC, xylose lysine deoxycholate (XLD) agar, and thiosulfate-citrate-bile salt-sucrose TCBS agar for the detection of Shigella spp., Aeromonas spp., Salmonella spp., and Vibrio spp. Subculture was done post enrichment in selenite $F$ broth and alkaline peptone water onto MAC, XLD, and TCBS, respectively [17].

\section{Detection of virulence genes and AMR genes in DEC}

Conventional PCR assay was used to detect 7 DEC pathogroup using 10 specific virulence genes as mentioned in Additional file 1: Tables S1 and S2. AMR genes (plasmid-borne) belonging to nine antimicrobial families and integron genes belonging to three classes of integrons were studied for all the confirmed DEC as mentioned in Additional file 1: Tables S1 and S2. The details of targeted genes, primer sequence, amplicon base pair size, reaction volume, and thermocycling conditions used as mentioned in Additional file 1: Tables S1 and S2. PCR was carried out in thermal cycler Eppendorf Mastercycler Nexus (Eppendorf, Hamburg, Germany).

\section{Gel electrophoresis}

Gel electrophoresis was performed using 1.5\% agarose (Sigma-Aldrich, USA) gel stained with ethidium bromide; 100 bp DNA Ladder (Genei Laboratories Pvt., Ltd., India) was used to measure the size of the amplicons (base pairs). Separated PCR products were visualized by Gel Doc XR System, Bio-Rad, Hercules, California, USA.

\section{Antimicrobial susceptibility testing}

DEC isolates were subjected to antimicrobial susceptibility testing. The disk diffusion test was performed according to Clinical and Laboratory Standards Institute guidelines for amikacin (30 $\mu \mathrm{g} /$ disk), gentamicin $(10 \mu \mathrm{g} /$ disk), ciprofloxacin (5 $\mu \mathrm{g} /$ disk), levofloxacin (5 $\mu \mathrm{g} /$ disk), tetracycline (30 $\mu \mathrm{g} /$ disk), 
chloramphenicol (30 $\mu \mathrm{g} /$ disk), co-trimoxazole (1.25/ $23.75 \mu \mathrm{g} /$ disk), cefoperazone-sulbactam (75/30 $\mu \mathrm{g} /$ disk), ceftazidime (30 $\mu \mathrm{g} /$ disk), and ceftriaxone (30 $\mu \mathrm{g} /$ disk); all these disks were procured from Bio-Rad, USA. ATCC 25922 (E. coli) was used as a quality control for antimicrobial susceptibility testing [18].

\section{Statistical analysis}

All categorical variables were expressed as percentages (\%). Chi-square test was used to find the association between categorical variables. Fisher's exact test was used wherever appropriate. Likelihood of finding AMR genes in DEC pathotypes harboring was calculated using odds ratio (OR) and 95\% confidence intervals (CIs), a $p$ value of $<0.05$ was considered statistically significant. Statistical analysis was performed using Epidata Analysis V2.2.3.187 and OpenEpi Version 3.01.

\section{Scientific and ethical assertion}

This study was approved by the JIPMER Scientific Advisory Committee (project no. JSAC 20/5/2015) and JIPMER Institute Ethics Committee for Human studies (project no. JIP/IEC/2015/15/743).

\section{Gene sequencing}

Sequencing was performed at BioServe Biotechnologies Pvt., Ltd. (Hyderabad, India). Aligned sequence (both forward and reverse) was searched in NCBI-BLAST (megablast) for the similarity of significant matches in the database. All the high similar nucleotide sequences were submitted to GenBank (NCBI).

\section{Results}

Prevalence of DEC pathogroups and other enteric bacterial pathogens in children and adults

Totally, 220 diarrhoeal stool specimens from children $(n=120)$ and adults $(n=100)$ were recruited in the study. Of the 120 children, $37.5 \%(n=45, p$-value $=0.01)$ and among the adults $(n=100), 18 \%(n=18, p$ value $=0.01)$ presented with diarrhea were found to be positive for one or more pathotype of DEC (Table 1). DEC co-infection was observed in $6.6 \%(n=3)$ of 45 DEC-infected children. While in adults $1 \%(n=1)$ co-infection was observed with a hybrid DEC strain containing genes of both EPEC (eaeA and $b f p A$ ) and ETEC (lt) along with atypical EPEC (only $b f p A$ gene was present). Apart from single and co-infection, $6.6 \%(n=3)$ children had hybrid DEC infection. In adults, no EIEC could detect. No CDEC and NTEC (CFN1 and CFN2) were detected in children and adults.

Other enteric bacterial pathogens detected in children and adults were Shigella spp. $[n=7(5.8 \%)$ and $n=4$ (4\%)], Aeromonas spp. $[n=1(0.83 \%)$ and $n=1(1 \%)]$, and Salmonella spp. [ $n=2(2 \%)$ detected only in adults].
Distribution of DEC according to age and gender (Table 1) Of the 120 children, 63\% $(n=76)$ were males and $37 \%$ $(n=44)$ were females, and among the 100 adults, $57 \%$ $(n=57)$ were males and $43 \%(n=43)$ were females (Table 1).

Out of 120 children, $51.6 \%$ were less than 12 months of age (Additional file 2: Table S3). While in adults, $44 \%$ were between 49 and 85 years (Additional file 2: Table S4). The proportion of DEC infections among these groups was more in children than in adults. EPEC was detected more in children less than 12 months of age followed by ETEC. The likelihood of finding EPEC $(n=21)$ was 5.1 times (OR 5.1; 95\% CI 1.478-23.72, $p \leq 0.05$ ) more than that of ETEC $(n=6)$. In adults, the likelihood of finding atypical EPEC $(n=10)$ was 2.7 times (OR 2.7; 95\% CI $0.8389-10.28, p \geq 0.05)$ more than that of ETEC $(n=4)$. However, the likelihood of finding atypical EPEC $(n=10)$ was 5.4 times (OR 5.4; 95\% CI 1.276-37.12, $p \leq 0.01$ ) more than that the odds of finding EAEC $(n=2)$.

\section{Detection of AMR genes in DEC strains isolated from children and adults}

All DEC strains isolated from children harbored one or more AMR gene. None of the isolates harbored qnrA, $q n r C$, qepA, tetE, tetC, tet $Y$, ermA, and $\operatorname{mor} 1$ genes. Among the integron genes, the int1 gene was found in $41.66 \%(n=20)$ of the strains, while int 2 and int 3 were not detected in any of these strains (Tables 2 and 3).

Unlike the strains isolated from children, only $73.68 \%$ ( $n=14$ ) of the DEC strains isolated from adults harbored one or more AMR genes. No AMR gene was detected in remaining $26.31 \%$ of strains. None of the isolates harbored qnrA, qnrC, qepA, tetD, tetE, tetC, tet $Y$, ermA, $m c r 1$, int2, and int3 genes. Atypical EPEC strains harbored utmost classes of AMR genes than other DEC pathotypes (Tables 2 and 3).

\section{Antimicrobial susceptibility testing}

Most of the DEC isolates phenotypically exhibited resistance for ceftriaxone $[n=33$ (49.2\%) $]$ followed by co-trimoxazole $[n=29(43.2 \%)]$, tetracycline $[n=24$ (35.8\%)], levofloxacin $[n=22(32.8 \%)]$, ciprofloxacin $[n=20$ (29.8\%)], ceftazidime $[n=18(26.2 \%)]$, gentamicin $[n=13$ (19.4\%)], chloramphenicol $[n=9(13.4 \%)]$, amikacin $[n=5$ (7.4\%)], and cefoperazone-sulbactam $[n=5$ (7.4\%)] (Table 4). Four types of pattern were observed while correlating phenotypic and genotypic resistance pattern of the DEC isolates (Table 5).

\section{Discussion}

DEC infection was the most common among children as well as adults, and atypical EPEC infection was high in number followed by typical EPEC in children whereas in adults only atypical EPEC infection was detected 


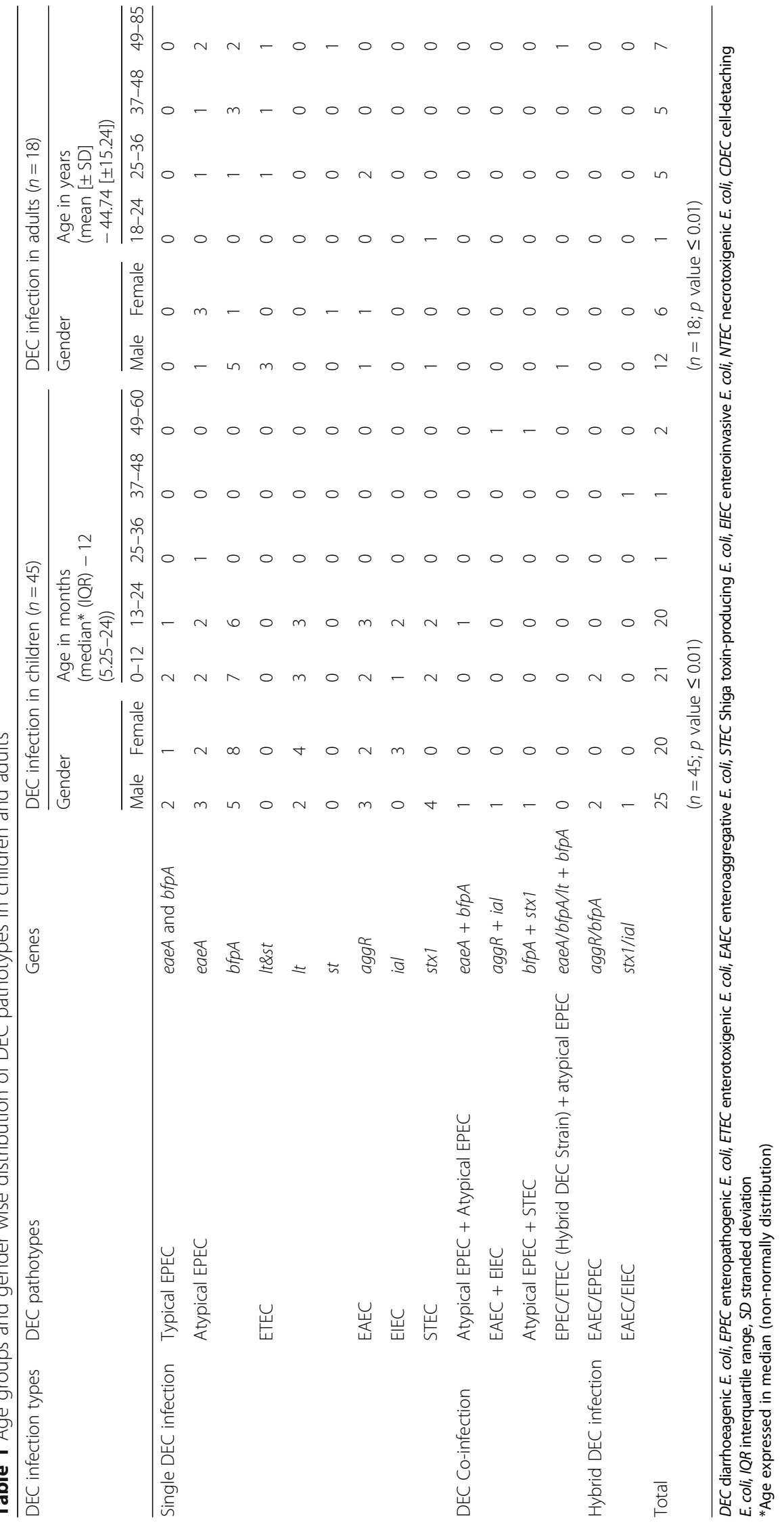




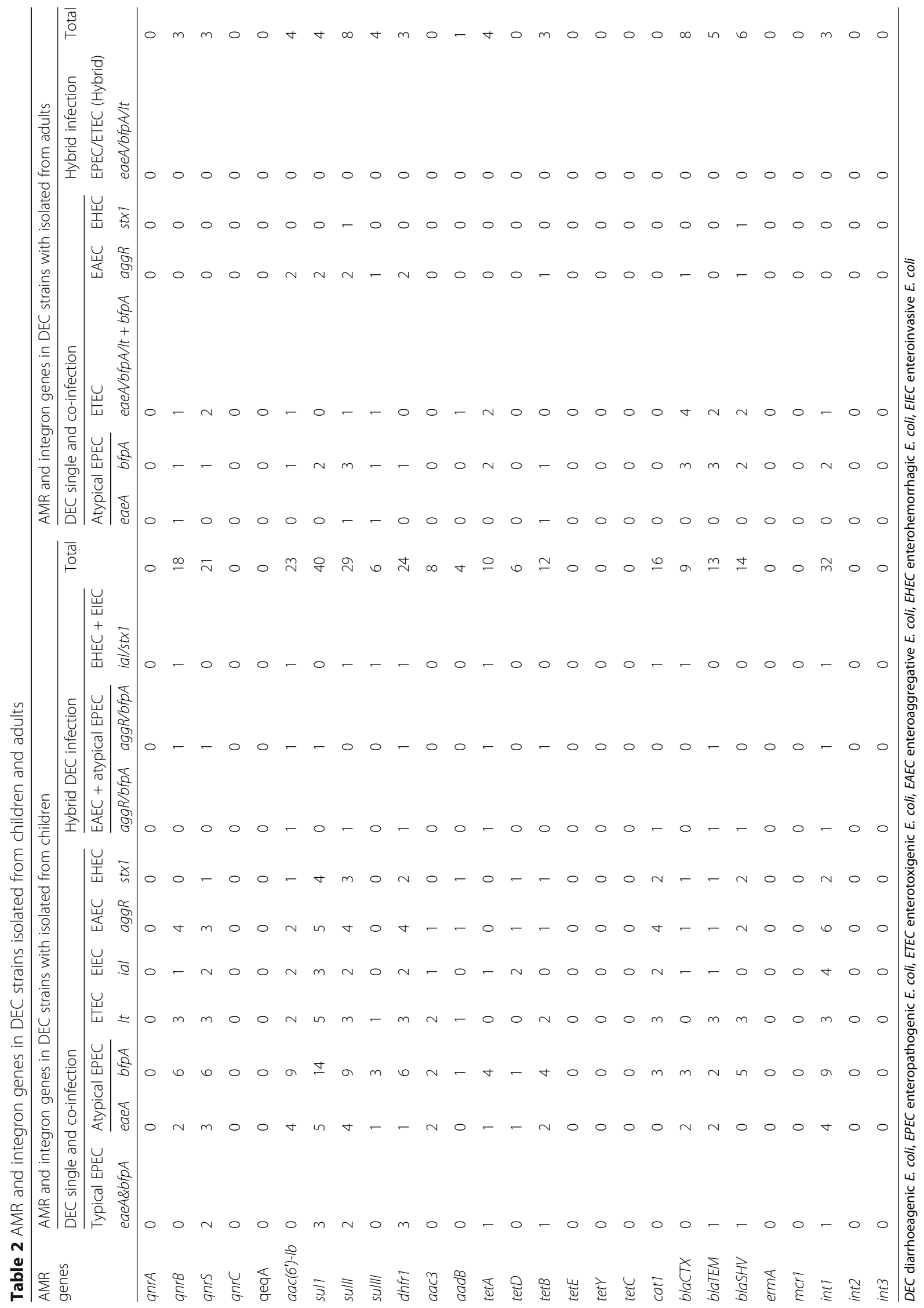




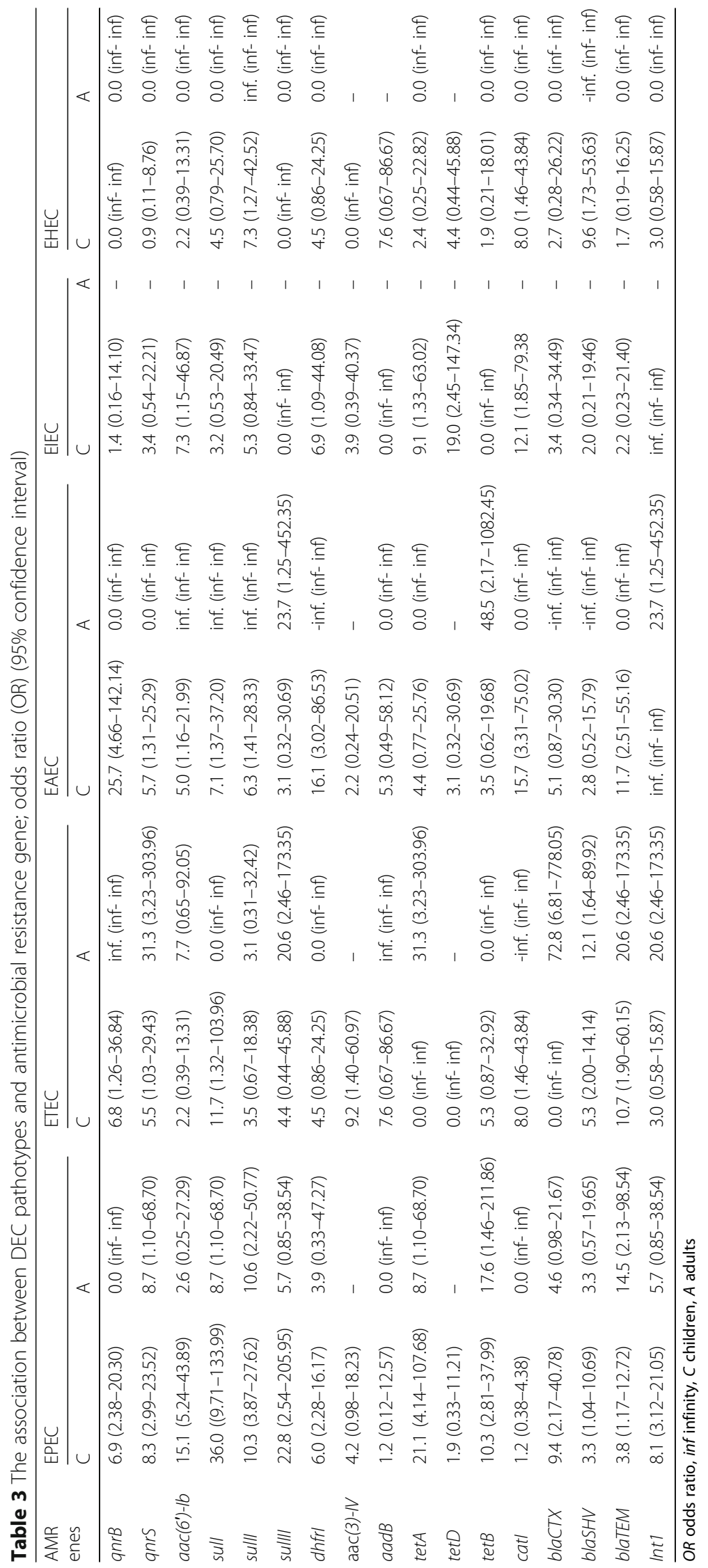


Table 4 Antibiogram of DEC isolates $(n=67)$

\begin{tabular}{|c|c|c|c|c|}
\hline Antimicrobial class & Antimicrobials & Resistance & Intermediate & Sensitivity \\
\hline \multirow[t]{3}{*}{$\beta$-lactam } & Ceftriaxone & $33(49.2 \%)$ & $1(1.4 \%)$ & $33(49.2 \%)$ \\
\hline & Ceftazidime & $18(26.8 \%)$ & $10(14.9 \%)$ & $39(58.2 \%)$ \\
\hline & Cefoperazone-sulbactam & $5(7.4 \%)$ & $0(0.0 \%)$ & $62(92.5 \%)$ \\
\hline Trimethoprim and sulfonamides & Co-trimoxazole & $29(43.2 \%)$ & $1(1.4 \%)$ & $37(55.2 \%)$ \\
\hline Tetracycline & Tetracycline & $24(35.8 \%)$ & $0(0.0 \%)$ & $43(64.1 \%)$ \\
\hline \multirow[t]{2}{*}{ Quinolones } & Levofloxacin & $22(32.8 \%)$ & $3(4.4 \%)$ & $42(62.6 \%)$ \\
\hline & Ciprofloxacin & $20(29.8 \%)$ & $11(16.4 \%)$ & $36(53.7 \%)$ \\
\hline \multirow[t]{2}{*}{ Aminoglycosides } & Gentamicin & $13(19.4 \%)$ & $2(2.9 \%)$ & $52(77.6 \%)$ \\
\hline & Amikacin & $5(7.4 \%)$ & $1(1.4 \%)$ & $61(91 \%)$ \\
\hline Phenicol & Chloramphenicol & $9(13.4 \%)$ & $2(2.9 \%)$ & $56(83.5 \%)$ \\
\hline
\end{tabular}

DEC diarrhoeagenic E.coli

(Table 1). Atypical EPEC is said to harbor only eaeA gene without EPEC adherence factor (EAF) plasmid (absence of $b f p A$ gene), whereas in typical EPEC both the genes eaeA and $b f p A$ are present. In our study interestingly, among the atypical EPEC detected, most were found to harbor $b f p A$ gene alone and very few strains were positive for the $e a e A$ gene. Variations in the distribution of atypical EPEC have been documented in earlier studies [19-24]. Atypical EPEC strain harboring eaeA gene without $b f p A$ gene was detected in the studies conducted in Brazil, North-West Italy, and Melbourne [19-21]. A study from Iraq documented only atypical EPEC harboring $b f p A$ without eaeA gene [22]. In a study conducted in Iran for both types of atypical EPEC, those harboring only eaeA and those harboring only $b f p A$ were detected [23]. Another study from India documented the isolation of atypical EPEC (harboring only eaeA gene) from children with diarrhea and atypical EPEC (harboring only $b f p A$ gene) from children without diarrhea in control group [24]. Hence, this indicates a mosaic distribution of the EPEC types with the atypical form emerging in many countries especially among the pediatric age group.

ETEC infection was common in children and adults next to EPEC infection. ETEC strains detected in children harbored only $l t$ gene whereas in adults ETEC strains $(n=3)$ harbored $l t$ and $s t$ and one strain of ETEC with only $s t$ gene was detected (Table 1 ). The reason for this strain variation among the adults and children is not so clear worldwide. Earlier study from India has documented no ETEC from children and adult [25]. ETEC is most commonly associated with traveler's diarrhea [4].

In our study, EAEC was detected in children (11.1\%) as well as in adults (2\%) (Table 1). In recent years, EAEC has emerged as diarrhoeal agent causing acute and chronic diarrhea in all age groups though it was once known to infect primarily newborns and immunocompromised patients [4]. Studies conducted in Mexico, Bolivia, Nicaragua, and Myanmar found that EAEC was the most common among all the DEC pathotypes [14, 26-28]. On the contrary, in our study, EPEC was the most common, similar to the findings of the studies conducted in Israel, Norway [29, 30]. Studies from India indicate a lower prevalence rate of EAEC [24, 31].

STEC was detected in four children and one adult. Since 2006, there have been numerous outbreaks in the USA, Germany, and France due to STEC infection, most of these outbreaks were associated with packed or readymade food items, e.g., outbreak due to raw clover

Table 5 Correlation between phenotypic and genotypic resistance pattern of the DEC isolates $(n=67)$

\begin{tabular}{|c|c|c|c|c|c|c|}
\hline Antimicrobial class & Antimicrobials & AMR genes detected & Pattern 1 & Pattern 2 & Pattern 3 & Pattern 4 \\
\hline Quinolones & Ciprofloxacin and levofloxacin & $a n r B, a n r S, a a c\left(6^{\prime}\right)-1 b$ & $13(19.4 \%)$ & $20(29.8 \%)$ & $9(13.4 \%)$ & $25(37.3 \%)$ \\
\hline Aminoglycosides & Amikacin and gentamicin & $a a c 3, a a d B$ & $42(62.6 \%)$ & $9(13.4 \%)$ & $9(13.4 \%)$ & $7(10.29 \%)$ \\
\hline Tetracycline & Tetracycline & tetA, tetB. tetD & $25(37.3 \%)$ & $13(19.4 \%)$ & $18(23.8 \%)$ & $11(16.4 \%)$ \\
\hline Phenicols & Chloramphenicol & cat1 & $44(65.6 \%)$ & $6(8.9 \%)$ & $12(17.9)$ & $5(7.4 \%)$ \\
\hline$\beta$-lactam & $\begin{array}{l}\text { Ceftazidime, ceftriaxone, } \\
\text { and cefoperazone-sulbactam }\end{array}$ & blaCTX, blaTEM, blaSHV & $15(22.5 \%)$ & $16(23.8 \%)$ & $13(19.4 \%)$ & $23(34.3 \%)$ \\
\hline Trimethoprim and sulfonamide & Co-trimoxazole & sul1, sulll, sulllI, dhfrr & $9(13.4 \%)$ & $1(1.4 \%)$ & $28(41.7 \%)$ & $29(43.2 \%)$ \\
\hline
\end{tabular}

Pattern 1: No resistance gene(s) detected and phenotypically sensitive

Pattern 2: No resistance gene(s) detected but phenotypically resistant

Pattern 3: Resistance gene(s) detected but phenotypically sensitive

Pattern 4: Resistance gene(s) detected and phenotypically resistant 
sprouts, and romaine lettuce [32]. STEC infection was less in both children and adults, and similar findings were documented in Kenya (0.2\%), Nicaragua (2.1\%), and Brazil (0.5\%) [33-35].

Similar to STEC, EIEC detected were less in number but only from children and none from adults (Table 1). Studies conducted in Gabon and South Western Nigeria reported that no EIEC could be detected in children [36, 37]. While earlier studies documented that EIEC infection was most common in developing and underdeveloped countries [4]. The reduced detection rate of EIEC infection in children and adults may be reflective of a changing ecology of the EIEC pathotypes because of improvement in the personal hygiene, safe food practice, and proper decontamination of drinking water [38, 39].

Apart from infection with a single pathotype, various combinations of DEC co-infection were observed in both children $(n=3)$ and adults $(n=1)$ (Table 1). Combination of three DEC strains was detected in a co-infection in a study conducted in Nicaragua (ETEC, atypical EPEC, EAEC) [34]. While a study conducted in South Western Nigeria reported a combination of four DEC strains [EHEC + EPEC + ETEC (LT) + EAEC] [40]. Co-infection of atypical EPEC was observed maximum in number than other DEC pathotypes.

The number of hybrid DEC strains observed in children $(n=3)$ was relatively more compared to that of adults $(n=1)$ (Table 1). About 1\% (DAEC-EAEC strain $(n=2)$, atypical EPEC-ETEC $(n=1))$ of children were infected with hybrid DEC strains in Mexico [41]. In another study conducted by Dutta et al. in Kolkata, India, an EPEC-ETEC hybrid strain was isolated from a child with acute diarrhea [42]. Increasing trends in the hybrid phenomenon between EAEC and EHEC strains was documented elsewhere [43-45]. A hybrid strain of ETEC and EHEC also reported from Finland [46]. A study from Brazil reported nine hybrid strains (EAEC harboring UPEC virulence marker) from patients with bacteremia and urinary tract infection (UTI) [47]. Hence, this clearly implies that such hybrid strains have become a common phenomenon among the pathogenic E. coli and are not restricted only to the DEC due to HGT. They emerge as potential outbreak agents in recent years leading to the high cause of morbidity and mortality. In addition, the increased severity of infection was noticed among the people who are infected with hybrid DEC strains and in DEC co-infections [44].

In children, all the DEC strains isolated were resistant to at least one class of antibiotic and 14 out of 19 DEC strains from adults harbored resistance genes for one or more class of antibiotics (Table 2). The EPEC strains were found to harbor more number of resistance genes of various class of antimicrobial agents followed by EAEC and ETEC. Since 1960, trimethoprim and sulphonamides have been one of the WHO's essential medicines, being easily affordable and very effective with a broad spectrum of activity against wide range of infection like diarrhea, cholera, UTI, and other extraintestinal infections. Recent studies have documented that trimethoprim and sulphonamide resistance genes are widespread being plasmid-borne, harbored by the bacteria inhabiting the aquatic bodies and in E. coli present in bio-fertilizers (cow dung) used in the agriculture as well as poultry farms [48]. These resistance genes are capable of circulating among the bacterial community through HGT. A transconjugation study conducted by Shuyu et al. showed that propagation of sul plasmid are majorly associated with incompatibility (IncF) replicons types (IncFI in sulI and IncFII in sullI) leading to resistance among the E. coli strains isolated from human stool specimen, and they also observed the co-transfer of other resistance genes [49]. Another transconjugation study conducted by Margarita Trobos et al. in E. coli strains found that sul2 gene was transferred along with blaTEM in human [50]. Majority of the DEC strains in our study harbored the trimethoprim and sulphonamides resistance genes (Table 2).

A major resistance mechanism of quinolone resistance in the Enterobacteriaceae is plasmid-mediated (PMQR). The most common PMQR resistance genes were qnrB, qnrS, and $a a c\left(6^{\prime}\right)-I b$. In children, all the pathotypes detected harbored either qnrS or qnrB genes or both, whereas, in adults, qnrS or qnrB was detected only in ETEC and atypical EPEC pathotypes (Table 1). A study from Spain reported qnrA and qurS genes in their DEC strains [51]. A study from Ahmedabad, India, found that $64.7 \%$ of the ETEC strains only harbored $a a c\left(6^{\prime}\right)-I b-c r$ gene without $q n r$ genes [52]. These studies suggest that dissemination of $q n r$ resistance genes among these DEC is variable.

Following sulphonamides and quinolone, resistance to $\beta$-lactams (plasmid-borne genes) was detected to be high in our study. In a study conducted by Ghorbani-Dalini et al., 96.3\% $(n=52)$ of DEC strains were found to harbor resistance genes to these antibiotics, blaTEM was positive in $83.33 \%$, blaSHV in $31.48 \%$, and blaCTX-M in $20.37 \%$ of adults [53]. In our study, majority of the DEC strains isolated from adults harbored blaCTX-M gene (57.1\%) while in children, the blaSHV gene (29.1\%) was more common (Table 2). In recent years, blaCTX has been the most predominant gene detected in $E$. coli in different parts of the world, particularly blaCTX-M-15 [54].

The frequency of aminoglycoside and chloramphenicol resistance varied among the DEC strains [55]. With reference to chloramphenicol resistance among $E$. coli, the major mechanism was inactivation of drugs by chloramphenicol acetyltransferase (CAT). cat 1 and cat 2 genes were most commonly distributed in E. coli strains worldwide since plasmid-borne, irrespective of the source of 
isolation [56, 57]. A study conducted by Yoo et al. found that low selective pressure was required for the transfer of chloramphenicol resistance genes among the bacteria isolated from aquatic regions [58]. This possibly indicates that such resistance genes and other AMR genes can be easily transferred by means of HGT as well leading to co-resistance.

Similar to aminoglycoside and chloramphenicol, tetracycline resistance genes are present in the plasmids harboring other drug resistance genes which can easily get transferred from one organism to the other by means of HGT, thus exhibiting the phenomenon of co-resistance to multiple antibiotics [59]. Due to broad-spectrum activity of tetracycline, it is widely used in veterinary practice to treat or prevent infections either through drinking water or feed [60]. A study from Ahmedabad, India, detected only $t e t A$, tet $B$, and tet $E$ genes without tetC, tetD, and tet $Y$ in the clinical isolates of ETEC in an outbreak [52]. We could not detect any tet $C$, tetE, or tet $Y$ genes in our strains (Table 2).

Many strains that harbored resistance genes were sensitive by phenotypic method which clearly implicates that these strains do not express the resistant genotype but act as a reservoir for these resistance genes. Meanwhile, resistance genes could not be detected in a few strains though they were phenotypically resistant, this could be due to the presence of other mechanisms of causing AMR such as efflux pumps.

Only class 1 integron (int1 gene) was detected in DEC stains isolated from both children and adults in our study (Table 2). A similar study from Iran reported only int 1 and int 2 genes while none of the DEC strains harbored int3 gene [61]. Studies from India also reported the presence of int1 and int2 genes in various DEC pathotypes $[52,62]$. Low prevalence of class 2 integron (int2 gene) and very rarely class 3 integron (int 3 genes) have been reported so far among these strains. Class 1 integron was primarily linked with antibiotic resistance among these strains. Next to conjugative plasmid, the newly emerged sulIII gene is carried out in class 1 integron [51]. Role of class 1 integron is predominant in spreading the multiple drug resistant genes among these DEC strains despite the emergence of class 2 and 3 integrons.

\section{Conclusion}

We observed that DEC is a potential diarrhoeal agent compared to other enteric bacterial pathogens in both children and adults in this study population. Atypical EPEC was most commonly encountered among DEC pathotypes. The emergence of atypical and DEC hybrid strains emphasize the importance of mobile genetic elements. Most of these DEC isolates were resistant to more than one antimicrobial agents and harbored integron genes, thus illustrating the importance of phenomenon of HGT arising due to the selective pressure of antibiotics. Thus, implementation of regulated use of antibiotics is the need of the hour in view of the availability of many antibiotics over the counter without the need of prescription, not completing the course of antibiotics, consumption of antibiotics when not indicated, and usage of antibiotics in animal feed. A surveillance network is thus needed and a mandatory reporting system to monitor these DEC strains and their AMR pattern for the effective control of diarrhoeal diseases.

\section{Additional files}

Additional file 1: Tables S1. and S2. The details of targeted genes and primer sequences. (DOCX $25 \mathrm{~kb}$ )

Additional file 2: Tables S3. and S4. Correlation of DEC infection rate with age groups. (DOCX $16 \mathrm{~kb}$ )

\section{Abbreviations \\ AMR: Antimicrobial resistance; bp: Base pair; CAT: Chloramphenicol acetyltransferase; CDEC: Cell-detaching E. coli; CFN: Cytotoxic necrotizing factors; Cls: Confidence intervals; DEC: Diarrhoeagenic Escherichia coli; \\ DNA: Deoxyribonucleic acid; EAEC: Enteroaggregative E. coli; EAF: EPEC adherence factor; EHEC: Enterohemorrhagic E. coli; EIEC: Enteroinvasive E. coli; EPEC: Enteropathogenic E. coli; ETEC: Enterotoxigenic E. coli; HGT: Horizontal gene transfer; HUS: Hemolytic-uremic syndrome; IQR: Interquartile range; LB: Luria-Bertani broth; NCBI: National Center for Biotechnology Information; NTEC: Necrotoxic E. coli; OR: Odds ratio; PMQR: Plasmid-mediated quinolone resistance; SD: Stranded deviation; STEC: Shiga toxin-producing E. coli; UTI: Urinary tract infection}

\section{Availability of data and materials}

All data generated or analyzed during this study are included in this manuscript [and its Additional files]. Please contact the corresponding author for any further data requests.

\section{Authors' contributions}

Dr. JM conceptualized the study design and did the final analysis of the experiments conducted and wrote the manuscript. Mr. MN and Dr. DK collected the specimens, performed all the assays, and contributed to the final manuscript. Dr. NB and Dr. SS contributed to the manuscript and performed critical analysis. All authors read and approved the final manuscript.

\section{Ethics approval and consent to participate}

JIPMER Institute Ethics Committee for Human studies (project no. JIP/IEC/ 2015/15/743) approved this study. Exemption from written or oral consent was obtained, since stool samples of patients with diarrhea are routinely submitted to the Microbiology laboratory at JIPMER for the isolation of diarrhoeal pathogens.

\section{Consent for publication}

Not applicable.

\section{Competing interests}

The authors declare that they have no competing interests.

\section{Publisher's Note}

Springer Nature remains neutral with regard to jurisdictional claims in published maps and institutional affiliations.

\section{Author details}

${ }^{1}$ Department of Microbiology, Jawaharlal Institute of Postgraduate Medical Education and Research (JIPMER), Puducherry 605006, India. ${ }^{2}$ Department of Paediatrics, Jawaharlal Institute of Postgraduate Medical Education and Research (JIPMER), Puducherry 605006, India. ${ }^{3}$ Department of Microbiology, 
Mahatma Gandhi Medical College and Research Institute (MGMC \& RI), Puducherry 607 402, India.

\section{Received: 24 February 2018 Accepted: 23 June 2018} Published online: 13 July 2018

\section{References}

1. WHO. Diarrhoeal disease. 2017. [cited 3 June 2017]. Available from: http:// www.who.int/mediacentre/factsheets/fs330/en/

2. National Health Mission. Government of India. IDCF 2017 Intensified Diarrhoea Control Fortnight 12-24 June 2017. 2017. http://www.nhm.gov. in/images/pdf/IDCF-2017/IDCF_guidelines_2017.pdf.

3. Acree M, Davis AM. Acute diarrhoeal infections in adults. JAMA. 2017; 318(10):957-8. https://doi.org/10.1001/jama.2017.8485.

4. Gomes TA, Elias WP, Scaletsky IC, Guth BE, Rodrigues JF, Piazza RM, et al. Diarrhoeagenic Escherichia coli. Braz J Microbiol. 2016;47(Suppl 1):3-30. https://doi.org/10.1016/.jbjm.2016.10.015.

5. Ordway NK. Diarrhoeal disease and its control. Bull World Health Organ. 1960;23(1):73-101.

6. Daniels N. Enterotoxigenic Escherichia coll: traveler's diarrhoea comes home. Clin Infect Dis. 2006:42(3):335-6.

7. Abduch FVL, Piantino FAJ, Reis da Silva PF, Brinkley C, Scaletsky IC. Celldetaching Escherichia coli (CDEC) strains from children with diarrhoea: identification of a protein with toxigenic activity. FEMS Microbiol Lett. 2002: 217(2):191-7.

8. Blanco J, González EA, Espinosa P, Blanco M, Garabal Jl, Alonso MP. Enterotoxigenic and necrotizing Escherichia coli in human diarrhoea in Spain. Eur J Epidemiol. 1992;8(4):548-52

9. Landers TF, Cohen B, Wittum TE, Larson EL. A review of antibiotic use in food animals: perspective, policy, and potential. Public Health Rep. 2012;127(1):4-22.

10. Bennett PM. Plasmid encoded antibiotic resistance: acquisition and transfer of antibiotic resistance genes in bacteria. Br J Pharmacol. 2009;153(Suppl 1): S347-57.

11. Uma B, Prabhakar K, Rajendran S, Kavitha K, Sarayu Y. Antibiotic sensitivity and plasmid profiles of Escherichia coli isolated from pediatric diarrhoea. J Glob Infect Dis. 2009;1 (2):107.

12. Okeke I, Aboderin O, Byarugaba D, Ojo K, Opintan J. Growing problem of multidrug-resistant enteric pathogens in Africa. Emerg Infect Dis. 2007; 13(11):1640-6

13. Thakur $\mathrm{N}$, Jain $\mathrm{S}$, Changotra $\mathrm{H}$, et al. Molecular characterization of diarrheagenic Escherichia coli pathotypes: Association of virulent genes, serogroups, and antibiotic resistance among moderate-to-severe diarrhea patients. J Clin Lab Anal. 2018; 32(5):e22388. https://doi.org/10.1002/jcla. 22388. Epub 2018 Jan 21.

14. Canizalez-Roman A, Flores-Villaseñor HM, Gonzalez-Nuñez E, et al. Surveillance of diarrhoeagenic Escherichia coli strains isolated from diarrhoea cases from children, Adults and Elderly at Northwest of Mexico. Front Microbiol. 2016;7:1924. eCollection 2016

15. Zhu XH, Tian L, Cheng ZJ, et al. Viral and bacterial etiology of acute diarrhoea among children under 5 years of age in Wuhan, China. Chin Med J (Engl). 2016;129(16):1939-44. https://doi.org/10.4103/0366-6999.187852.

16. Dias RCB, Dos Santos BC, Dos Santos LF, et al. Diarrhoeagenic Escherichia coll pathotypes investigation revealed atypical enteropathogenic E. coli as putative emerging diarrhoeal agents in children living in Botucatu, São Paulo state, Brazil. APMIS. 2016;124(4):299-308. https://doi.org/10.1111/apm.12501.

17. ICMR. Standard operating procedures bacteriology antimicrobial resistance surveillance and research network. Indian Council of Medical Research: New Delhi; 2015.

18. CLSI. Performance standards for antimicrobial susceptibility testing: twentyfifth informational supplement. CLSI document M100-S25 Wayne: Clinical and Laboratory Standards Institute; 2015.

19. Matos NB, Pieri FA, Penatti M, Orlandi PP. Adherence and virulence genes of Escherichia coli from children diarrhoea in the Brazilian Amazon. Braz J Microbiol. 2015;46(1):131-7.

20. Amisano G, Fornasero S, Migliaretti G, Caramello S, Tarasco V, Savino F. Diarrhoeagenic Escherichia coli in acute gastroenteritis in infants in NorthWest Italy. New Microbiol. 2011;34(1):45-51. Epub 2011 Jan 15

21. Nguyen RN, Taylor LS, Tauschek M, Robins-Browne RM. Atypical enteropathogenic Escherichia coli infection and prolonged diarrhoea in children. Emerg Infect Dis. 2006;12(4):597-603.
22. Hilali AAS, Almohana AA. Occurrence and molecular characterization of enteropathogenic Escherichia coli serotypes isolated from children with diarrhoea in Najaf, Iraq. Indian J Med Microbiol. 2011;29(4):383-8.

23. Aslani MM, Alikhani MY. Molecular and phenotypic characterization of atypical enteropathogenic Escherichia coli serotypes isolated from children with and without diarrhoea. J Microbiol Immunol Infect. 2011; 44(1):27-32.

24. Hegde A, Ballal M, Shenoy S. Detection of diarrhoeagenic Escherichia coli by multiplex PCR. Indian J Med Microbiol. 2012;30(3):279-84.

25. Shetty VA, Kumar SH, Shetty AK, Karunasagar I, Karunasagar I. Prevalence and characterization of diarrhoeagenic Escherichia coli isolated from adults and children in Mangalore. India J Lab Phys. 2012;4:24-9.

26. Gonzales L, Joffre E, Rivera R, Sjöling Å, Svennerholm AM, Iñiguez V. Prevalence, seasonality and severity of disease caused by pathogenic Escherichia coli in children with diarrhoea in Bolivia. J Med Microbiol. 2013; 62(Pt 11):1697-706. https://doi.org/10.1099/jmm.0.060798-0.

27. Reyes D, Vilchez S, Paniaqua M, Colque-Navarro P, Weintraub A, Möllby R, et al. Diarrhoeagenic Escherichia coli markers and phenotypes among fecal E. Coli isolates collected from Nicaraguan infants. J Clin Microbiol. 2010; 48(9):3395-6.

28. Takahashi E, Sultan Z, Shimada S, Aung WW, Nyein MM, Oo KN, et al. Studies on diarrhoeagenic Escherichia coli isolated from children with diarrhoea in Myanmar. Microbiol Immunol. 2008;52(1):2-8.

29. Tobias J, Kassem E, Rubinstein U, Bialik A, Vutukuru SR, Navaro A, et al. Involvement of main diarrhoeagenic Escherichia coli, with emphasis on enteroaggregative $E$. coli, in severe non-epidemic pediatric diarrhoea in a high-income country. BMC Infect Dis. 2015;15:79. https://doi.org/10.1186/ s12879-015-0804-4.

30. Afset JE, Bevanger $L$, Romundstad P, Bergh K. Association of atypical enteropathogenic Escherichia coli (EPEC) with prolonged diarrhoea. J Med Microbiol. 2004;53(Pt 11):1137-44.

31. Anvikar AR, Dolla C, Dutta S, et al. Role of Escherichia coli in acute diarrhoea in tribal preschool children of Central India. Paediatr Perinat Epidemiol. 2008;22(1):40-6. https://doi.org/10.1111/j.1365-3016.2007.00892.x.

32. Cdc.gov. List of selected multistate foodborne outbreak investigations. Foodborne Outbreaks. Food Safety. CDC [Internet]. 2017 [cited 27 July 2017]. Available from: https://www.cdc.gov/foodsafety/outbreaks/multistateoutbreaks/outbreaks-list.html

33. Shah M, Kathiiko C, Wada A, Odoyo E, Bundi M, Miringu G, et al. Prevalence, seasonal variation, and antibiotic resistance pattern of enteric bacterial pathogens among hospitalized diarrheic children in suburban regions of Central Kenya. Trop Med Health. 2016;44:39. https://doi.org/10.1186/s41182-016-0038-1.

34. Vilchez S, Reyes D, Paniagua M, Bucardo F, Möllby R, Weintraub A. Prevalence of diarrhoeagenic Escherichia coli in children from León, Nicaragua. J Med Microbiol. 2009:58(Pt 5):630-7. https://doi.org/10.1099/jmm.0.007369-0.

35. Araujo JM, Tabarellia GF, Aranda KR, Fabbricotti SH, Fagundes-Neto U, Mendes CMF, et al. Typical enteroaggregative and atypical enteropathogenic types of Escherichia coli are the most prevalent diarrhoea-associated pathotypes among Brazilian children. J ClinMicrobiol. 2007:45(10):3396-9.

36. Presterl E, Zwick RH, Reichmann S, Aichelburg A, Winkler S, Kremsner PG, et al. Frequency and virulence properties of diarrhoeagenic Escherichia coli in children with diarrhoea in Gabon. Am J Trop Med Hyg. 2003;69(4):406-10.

37. Odetoyin WB, Hofmann J, Aboderin OA, Okeke IN. DiarrhoeagenicEscherichia coli in mother-child pairs in lle-lfe, South Western Nigeria. BMC Infect Dis. 2015;16:28. https://doi.org/10.1186/s12879-016-1365-x.

38. Donnenberg M. Escherichia coli: pathotypes and principles of pathogenesis. 2nd ed. USA: Academic Press; 2013

39. Onanuga A, Igbeneghu O, Lamikanra A. A study of the prevalence of diarrhoeagenic Escherichia coli in children from Gwagwalada, Federal Capital Territory, Nigeria. Pan Afr Med J. 2014;17:146. https://doi.org/10, 11604/pamj.2014.17.146.3369.

40. Odetoyin WB, Hofmann J, Aboderin OA, Okeke IN. Diarrhoeagenic Escherichia coli in mother-child pairs in lle-lfe, South Western Nigeria. BMC Infect Dis. 2015;16:28. https://doi.org/10.1186/s12879-016-1365-x.

41. Patzi-Vargas S, Zaidi M, Perez-Martinez I, León-Cen M, Michel-Ayala A, Chaussabel D. Diarrhoeagenic Escherichia coli carrying supplementary virulence genes are an important cause of moderate to severe diarrhoeal disease in Mexico. PLoS Negl Trop Dis. 2015;9(3):e0003510.

42. Dutta S, Pazhani GP, Nataro J, Ramamurthy T. Heterogenic virulence in a diarrhoeagenic Escherichia coli: evidence for an EPEC expressing heat-labile toxin of ETEC. Int J Med Microbiol. 2015;305(1):47-54. 
43. Prager R, Lang C, Aurass P, Fruth A, Tietze E, Flieger A. Two novel EHEC/EAEC hybrid strains isolated from human infections. PLoS One. 2014;9(4):e95379.

44. Borgatta B, Kmet-Lunaček N, Rello J. E. coli O104:H4 outbreak and haemolytic-uraemic syndrome. Med Int. 2012;36(8):576-83. https://doi.org/ 10.1016/j.medin.2011.11.022.

45. Jensen BH, Olsen KEP, Struve C, Krogfelt KA, Petersen AM. Epidemiology and clinical manifestations of Enteroaggregative Escherichia coli. Clin Microbiol Rev. 2014;27:614-30. https://doi.org/10.1128/CMR.00112-13.

46. Nyholm O, Heinikainen S, Pelkonen S, Hallanvuo S, Haukka K, Siitonen A. Hybrids of Shigatoxigenic and enterotoxigenic Escherichia coli (STEC/ETEC) among human and animal isolates in Finland. Zoonoses Public Health. 2015;62:518-24. https://doi.org/10.1111/zph.12177.

47. Lara FBM, Nery DR, De Oliveira PM, Araujo ML, Carvalho FRQ, Messias-Silva LCF, et al. Virulence markers and phylogenetic analysis of Escherichia coli strains with hybrid EAEC/UPEC genotypes recovered from sporadic cases of extraintestinal infections. Front Microbiol. 2017:8:146. https://doi.org/10. 3389/fmicb.2017.00146.

48. Wang N, Yang X, Jiao S, Zhang J, Ye B, Gao S. Sulfonamide-resistant bacteria and their resistance genes in soils fertilized with manures from Jiangsu Province, Southeastern China. PLoS One. 2014;9(11):e112626. https://doi.org/ 10.1371/journal.pone.0112626.

49. Wu S, Dalsgaard A, Hammerum AM, Porsbo LJ, Jensen LB. Prevalence and characterization of plasmids carrying sulfonamide resistance genes among Escherichia coli from pigs, pig carcasses and human. Acta Vet Scand. 2010; 52:47. https://doi.org/10.1186/1751-0147-52-47.

50. Trobos M, Christensen H, Sunde M, Nordentoft S, Agersø Y, Simonsen GS, et al. Characterization of sulphonamide-resistant Escherichia coli using comparison of sul2 gene sequences and multilocus sequence typing. Microbiology. 2009;155(Pt 3):831-6. https://doi.org/10.1099/mic.0.024190-0.

51. Herrera-León S, Llorente MT, Sánchez S. Plasmid-mediated quinolone resistance in different diarrhoeagenic Escherichia coli pathotypes responsible for complicated, noncomplicated, and traveler's diarrhoea cases. Antimicrob Agents Chemother. 2015;60(3):1950-1. https://doi.org/10.1128/AAC.02909-15.

52. Pazhani GP, Chakraborty S, Fujihara K, Yamasaki S, Ghosh A, Nair GB. QRDR mutations, efflux system \& antimicrobial resistance genes in enterotoxigenic Escherichia coli isolated from an outbreak of diarrhoea in Ahmedabad, India. Indian J Med Res. 2011;134:214-23.

53. Memariani M, Peerayeh SN, Salehi TZ, Mostafavi SKS. Occurrence of SHV, TEM and CTX-M $\beta$-lactamase genes among enteropathogenic Escherichia coli strains isolated from children with diarrhoea. Jundishapur J Microbiol. 2015;8(4):e15620

54. Ghorbani-Dalini S, Kargar M, Doosti A, Abbasi P, Sarshar M. Molecular epidemiology of ESBL genes and multi-drug resistance in diarrhoeagenic Escherichia Coli strains isolated from adults in Iran. Iran J Pharm Res. 2015;14(4):1257-62.

55. Economou V, Gousia P. Agriculture and food animals as a source of antimicrobial-resistant bacteria. Infect Drug Resist. 2015;8:49-61. https://doi. org/10.2147/IDR.S55778.

56. Li XS, Wang GQ, Du XD, Cui BA, Zhang SM, Shen JZ. Antimicrobial susceptibility and molecular detection of chloramphenicol and florfenicol resistance among Escherichia coli isolates from diseased chickens. J Vet Sci. 2007;8(3):243-7.

57. Heidary M, Momtaz H, Madani M. Characterization of diarrhoeagenic antimicrobial resistant Escherichia coli isolated from pediatric patients in Tehran. Iran Iran Red Crescent Med J. 2014:16(4):e12329. https:/doi.org/10.5812/ircmj.12329.

58. Yoo MH, Huh MD, Kim EH, Lee HH, Jeong HD. Characterization of chloramphenicol acetyltransferase gene by multiplex polymerase chain reaction in multidrug-resistant strains isolated from aquatic environments. Aquaculture. 2003;217:11-21.

59. Speer BS, Shoemaker NB, Salyers AA. Bacterial resistance to tetracycline: mechanisms, transfer, and clinical significance. Clin Microbiol Rev. 1992;5(4):387-99.

60. Granados-Chinchilla F., Rodriguez C. Tetracyclines in food and feeding stuffs: from regulation to analytical methods, bacterial resistance, and environmental and health implications. J Anal Methods Chem. 2017; 2017 doi: https://doi.org/10.1155/2017/1315497

61. Zeighami H, Haghi F, Masumian N, Hemmati F, Samei A, Naderi G. Distribution of integrons and gene cassettes among Uropathogenic and Diarrhoeagenic Escherichia coli isolates in Iran. Microb Drug Resist. 2015; 21(4):435-40. https://doi.org/10.1089/mdr.2014.0147.

62. Singh T, Das S, Ramachandran VG, Wani S, Dheeraj S, Marrof KA, et al. Distribution of integrons and phylogenetic groups among enteropathogenic Escherichia coli isolates from children $<5$ years of age in Delhi, India. Front Microbiol. 2017;8:561. https://doi.org/10.3389/fmicb.2017.00561.

\section{Ready to submit your research? Choose BMC and benefit from:}

- fast, convenient online submission

- thorough peer review by experienced researchers in your field

- rapid publication on acceptance

- support for research data, including large and complex data types

- gold Open Access which fosters wider collaboration and increased citations

- maximum visibility for your research: over $100 \mathrm{M}$ website views per year

At BMC, research is always in progress.

Learn more biomedcentral.com/submissions 